\title{
Conflicting Emotions: Globalization and Decoloniality in También la lluvia
}

\begin{abstract}
Erika Bondi
Arizona State University

It is not difficult to understand the success of También la lluvia (2010) starring the internationally recognized Mexican actor Gael García Bernal. The coproduction among France, Spain, and Mexico succeeds in creating film that gains critical as well as commercial attention for its treatment of the theme of globalization as well as for its aesthetic quality. The Spanish director, Icíar Boallaín heavily employs metacinematography, metanarrative, and intertextuality in the film but loses subtlety in conveying the message of globalization as a continuation of colonization. As the study of the aforementioned themes has been exhausted, this analysis focuses on the role and representation of the emotions that are shaped by the global economic circumstance of capitalism, consumerism, and globalization. I will analyze and compare the emotions of the western characters with that of the indigenous characters in Bolivia to demonstrate how the filmic representations of emotions are influenced by the understanding of history, culture, and society. This analysis attempts to reveal how the western subjects struggle to locate their emotions resulting in their displacement in representations of information and simulations of reality that have lost their connection with the original referent. On the other hand, the indigenous' emotional repertoire is based on their direct interaction with the land and their community. Furthermore, the first people appear to have inherited and cultivated their emotions as a community, which motivate them to act collectively to continue their incessant struggle against exploitation and colonization. Through this study, I hope to explore the relationship between the emotions and decoloniality by identifying how cultivation of emotions could have a major impact in questioning the Eurocentric episteme imposed onto the periphery.
\end{abstract}

Keywords: decoloniality, emotions, emotionology, postemotionalism, latin American film

También la lluvia (2010) or Even the Rain, directed by the Spaniard, Iciár Boallín, is a multilayered film with a plot that unfolds in Cochabamba, Bolivia in the year 2000. The main narrative follows Sebastian, a film director (Gabriel García Bernal) and his producer, Costa (Luis Tosar) in their attempt to shoot a movie about Columbus's conquest of the Americas. A second narrative frame consisting of the first people's resistance against the privatization of water by a foreign multinational company lies as the backdrop of the main plot. The final narrative frame is imbedded through María's (Cassandra Ciangherotti) documentary about Sebastian's movie, which turns into her attempt to film the natives' resistance against the privatization of water. María's cinematographic aesthetic of the guerilla filmmaking in black and white alludes to the Latin American New Cinema. ${ }^{1}$ Boallín also incorporates an allusion to the opening scene of La Dolce Vita (1960) with a helicopter

Erika Bondi, Ph.D., Department of Spanish Literature and Culture, Arizona State University, USA; main research fields: Latin American Narratives, Philosophy and History of Emotions, and 20th Century Novel. 
flying in with the gigantic cross that would be used as a prop for Sebastián's movie. This is a reference to Federico Fellini, the neorealist filmmaker that heavily influenced directors of the New Cinema movement of the 1960s and 1970s. There are many parallels between reality and history in the self-reflexive film. First is the irony of making a movie that denounces the exploitation of the natives by the Spanish Crown at the expense of perpetuating the same abuses towards the natives in Bolivia for cheap labor to produce the film. Second is the critique on the effects of globalization on filmmaking implied with coproduction dependent on funding from English-speaking investors and more importantly English-speaking viewers. Finally, it is the mise-en-scene based on the real events regarding the agreement among the World Bank, the Bechtel Corporation, and the Banzer government, which lead to the Water Wars of the early $2000 \mathrm{s.}^{2}$

This study analyzes the emotions represented in the film to reveal how the effects of globalization shape them. It will focus on the collective emotional standards influenced by western epistemology and native Cosmo vision as presented in the film. It is my contention that the western emotionology firmly bound to the rationality of the capitalist market, whereas the first people's are deeply rooted in their traditional spiritual connection as a community to the Pachamama (Earth). The emotions governed by distinct historical and cultural processes collide in the film, in the same manner as the postmodern commercial and new cinema aesthetics do. Nevertheless, it is crucial to keep in mind that this is merely one perspective offered by a Spanish filmmaker on the topic of neoliberal policies and their effects on Latin American developing countries. The purpose is not to establish an all encompassing truth of the (non)western emotional standards, but rather to demonstrate that there is an undeniable connection between socio-cultural and political mores of a society and the formation of emotional standards, expressions, and processes that are depicted in its cultural production. It is necessary to first establish the emotionalogical framework for all the western capitalist, consumer society, and indigenous collective social structure represented in the film to understand the way that the emotions are interconnected with society and culture.

In The Rationality of Emotions (1989), Ronald de Sousa proposes that emotions are formed through paradigm scenarios in which the individual learns appropriate emotional responses by engaging with the world and others in order to build on an emotional repertoire that is based on societal values and norms. Indeed, it is through human development within a specific socio-cultural context that individuals learn and acquire emotions that draw them from the basic instinctual biological response into the intentional world (186). Based on this understanding of the emotions as functioning in accordance with rationality and is firmly linked to goals and motivation, it is not difficult to see how emotionology evolves throughout history within different socio-cultural, political, and economic systems. We will see how the movie represents the emotions as firmly bound to the globalized capitalist system as depicted in the emotional standards of the western characters (film crew, government officials) that are linked to the individualist mentality driven by the rationality of the capitalist market.

Although emotions have been problematic for the project of Enlightenment and Modernity, it certainly does not eliminate them from the scene. Instead, they are controlled, repressed, programmed, and standardized to work in accordance with the political and economic situation of the time. Jack Barbalet recognizes the connection between the logic of the market and the emotions based off of readings of Max Weber and Georg Simmel. He notes that Weber's theory eliminates emotions from the rationality of the capitalist market, whereas Simmel recognizes the emotional patterns that complement the market, as Barbalet observes: “... the displacement of emotion by rationality is not the end of emotion, and the source of the rational orientation is 
not simply the market but the emotional pattern that the market promotes" (Emotion, Social Theory, and Social Structure: A Macrosociological Approach, 1998, 55). The emotions are not disruptions to rationality but instead are connected to motivation and action within the capitalist system. Indeed, the emotions are at the core of the highly calculative and rational capitalism whether they are manipulated to coincide with the market or cultivated for the "commitment to the purpose at hand, loyalty to the employing organization, joy in success to encourage more success, and dissatisfaction at failure to encourage success, trust in those with whom cooperation is necessary, envy of competitors to spur the pursuit of interests, and greed to encourage aggrandizement" (59).

The emotions shaped by the capitalist society are most evident in Costa's character as the executive producer of the film. His blatant indifference towards the indigenous people's struggle and ambition to complete the film in the most efficient and cost-effective way demonstrates that he is governed by the rationality of the market. He consistently makes comments regarding cheap labor in front of the people that he is exploiting. He puts the lives of the workers in danger to keep the cost down and depends on money as the answer to all of the problems he encounters from bribing corrupt officials, to paying off Daniel (Juan Carlos Anduviri), the native that plays the role of Hatuey, in order to guarantee the completion of the film. His relationships are strictly based on business including with his good friend Sebastián as they work as a team to produce a product for consumption. From his interaction with Antón (Karra Elejalde), the actor cast as Columbus, the audience learns that Costa is a solitary and estranged individual, disconnected from his son as his life centers on his work, which could be read as his way of displacing his sadness regarding his family life. Nevertheless, Costa is one of the two characters that consistently displays authentic emotions shaped by his capitalist society but is also genuinely affected by his first hand encounter with the native people. He has also evolved the most by way of the empathy that he experiences from his interaction and connection with Daniel's family. In the end of the movie, he was not able to deny Daniel's wife his help in finding Belén, their daughter, to take to the hospital in the midst of the violent demonstration. Costa deviates from his individualistic emotional framework and falls back to the basic human emotion of empathy to help Belen. In the end of the movie, Daniel gives him a vial of "yaku" (water), signifying his deep appreciation to Costa for saving his daughter's life, regardless of their differences. Costa hugs Daniel goodbye and holds back his tears, as is expected of a businessman in his culture. An understanding between the value of water and life is solidified in Costa's mind during his cab ride out of the city. The film leaves the audience with hope by showing the most alienated character with the least compassion and knowledge of the first people as able to evolve by emotionally engaging with the other, thereby affirming that emotions are malleable and can change the way an individual navigates through the world.

Conversely, Sebastián is motivated by artistic creation of the film rather than the profits and budget. His character is relgated from the beginning as the sensitive artist as he shows concern for the dangerous work situations that the natives are subjected to while Costa insists that it is well worth the money that they would be saving. Although his emotives reflect his liberal sentiment for justice, his actions do not. Sebastián's motivation is also associated with his individualist ego masked by a leftist political sensibility that he fails to preserve throughout the production of the film. The young director is moved by information that he has read about Bartolomé de las Casas and Antonio Montesinos. His interpretation of the legend of Hatuey and Columbus's first encounter with the Tainos evoke romantic emotions in the artist that ignite his passion for the project. Nevertheless, his sensitivity wanes once the filming starts to face some cultural difficulties with the natives. 
Sebastian can be considered an example of Stjepan Meštrović's concept of a postemotional type in the sense that he displaces his emotions onto his film, a simulation of historical accounts. That is not to say that Sebastian does not feel real sadness or empathy for the plight of the first peoples, but that he manifests these emotions through his movie scenes rather than the actual people. For instance, he cries when he reads his script and visualizes the scene of the escape of the Tainos in which a dog attacks an old indigenous woman that is left behind. In reality, the only emotion he expresses towards the natives is anger for the women that refused to fake the drowning of their babies. He does not demonstrate an ounce of empathy for their situation nor does he even try to understand their perspective. His emotions are tied up in the fictionalized narratives that he has created for the displacement of his emotions.

It seems that the western emotions evoked by the natives are associated with information and representation such as the tragic narrative of the Tainos and the indigenous language that amuses Alberto (Carlos Santos), the actor in the role of Las Casas at dinner. This reflects Mestrovic's notion of the displacement of emotions on information in postemotionalism:

Instead of the circulation of fictions described by Baudrillard, it is more accurate to point to the co-existence of reality with emotionally charged "fictions," or what might be termed circulating emotions... I am implying a concrete world of rooted fictions saturated with emotions that are displaced, misplaced, and manipulated by the culture industry. (Postemotional Society, 1996, 39)

Meštrović claims that the emotions never disappear from society, but rather that postmodern subjects are left with a plethora of repressed emotions that are displaced in products of consumption, cultural practices, vicarious experiences, and humanitarian causes etc. (26). Meštrović refers to this phenomenon as emotional luxury experienced by those that "feel for everyone and everything past present future" without ever truly committing emotionally to a cause so that it would manifest into action. This is represented by way of the actors and crew that chose to abandon the project in the end. Even María, as a postemotional subject, could not commit to her guerrilla filmmaking of the Water Wars. Sebastián was never able to abide by his leftist values, for example his agreement to Daniel's arrest after they finished filming knowing that he would be subjected to physical abuse and torchure. Therefore, the westerners may claim to be emotionally committed to the natives and human rights, yet their actions contradict their luxurious emotions. These emotions are not sincere or authentic by any means, instead they "... lead to compassion fatigue, anomie, as the malady of infinite desire that can never be satisfied, and a diffuse anxiety that colors almost every waking hour, among other pathologies" (33). The fast paced western society that has access to information and any form of stimulation for entertainment by way of technology and in which one can purchase emotions and experiences by way of consumerism is the environment that produces postemotional subjects such as Sebastián and his actors.

While Sebastián and the actors feign their romantic leftist sensibilities, Antón is a flawed character that never wears a mask to hide his authentic emotions even though he is the harshest of the characters. He is a depressed lonely man that displaces his discontent in alcohol while attempting to sustain a connection with his family from which he is estranged. He does not buy the narrative that Sebastian attempts to sell regarding the glorification of Las Casas and calls him out on his "propaganda." He challenges Alberto's veneration of Las Casas by pointing out information that was left out of the movie script, such as the fact that he proposed to replace Indian slaves with Africans. What interests Antón as an actor are the anxieties and the doubts that his character would have faced in his situation, yet at the same time he admits that he is only there for the money. 
Nevertheless, he is the only one who stays to complete the movie out of respect for the natives and commits to his authentic emotions through the act of charity of offering apprehended natives a drink and by reprimanding the police officers for their mistreatment. Throughout the film, Antón functions as an authentic individual that displays real emotions and does not hesitate to express his thoughts honestly without fear of judgment of others. The concept of a self-regulated emotionology dramatized in Antón's rebellious stance towards his superficial colleagues who want to keep it cool and relaxed at dinner by evading the reality around them, echoes what Peter Stearns proposes in American Cool: Constructing a Twentieth-Century Emotional Style (1994). Stearns observes that although the 20th century is known for individualism, freedom of expression and deregulation of the emotions, in reality the market and corporate culture had created a self regulating society that strengthened the conformist desire to identify with groups and major institutions, which are governed by the consumerist market $(1994,192)$. The fear of exclusion and embarrassment keeps individuals in line while maintaining the illusion of complete freedom. In this way, Antón and Costa are complex characters that display authentic emotions that deviate from the emotional standards of their capitalist consumer culture in the sense that they act outside of the western individualist emotional framework through their empathy. In this way, the movie illustrates how emotions are directly linked to the socio-cultural situation and can be transformed by way of authentic experiences with others, and in this case, the "other."

The second category of emotions is the collective emotions shaped by the first people's history and cosmology that are deeply rooted in the land. This is challenged in the age of globalization in which rampant expansion and development by Multi-national Corporations result in the displacement of many indigenous communities. Although the natives in the film are not necessarily displaced, the foreign corporations are depleting their resources. While the westerners individually experience the anger related to work and money, the natives collectively display anger when their livelihood is threatened. They are deeply committed to the anger that provokes them to act as a community against the Corporation and the Government that impede them from living their lives in accordance with their concept of "sumak kawsay" or "suma kamaña." In The Darker Side of Western Modernity (2011), Walter Mignolo explains this concept as "to live in harmony," which implies coexistence with all living organisms including the Pachamama and all of its inhabitants (307). Mignolo refers to Bolivia in his text as an example of the decolonial movement which strives for a pluriversal world in which multiple ways of living are recognized as opposed to a single homogenized system. The collective manifestation of the emotions of the native people through action and resistance in the film underscores the decolonial process taking shape, which Mignolo defines as "an option for delinking from Westernization, in the past, and from rewesternization both in the present and toward the future" (327). The natives are not necessarily in a struggle against globalization, as they willingly work for the movie, understanding that they have to survive within the system. Instead, the indigenous struggle is based on their ability to live in alignment with their Cosmo vision, which in this case is inhibited by the privatization of the community's water. Their communal way of life is simply one alternative to the capitalist society.

The collective emotion of anger is linked to the Andean Cosmo vision but also is deeply rooted in the long history of abuse that the natives have endured since the conquest, as the government official tells Sebastián regarding the natives in his discourse about globalization in Bolivia: "Llevan la desconfianza en sus genes" or "they carry distrust in their dna." The idea that the emotions are inherited suggests that, not much has changed since the conquest and reaffirms the message of neoliberalism and globalization as new forms of colonization. Indeed, Bolivia has historically experienced colonial abuse of the indigenous and their land, for instance, Cerro 
Rico in Potosí, a silver mine that bankrolled the Spanish Empire during their colonial expansion. The country also has a long account of indigenismo that demystifies the romantic image of the stoic passive Indian and demonstrates that they are an agential community that organize to protest and fight for their way of life and land. These emotions are sustained throughout history and are displayed through protest, rebellions, and even political action as we see in the 21 st century with Evo Morales, the first indigenous president to be elected in Latin America. In the movie, we see how anger and distrust circulate among the men and women alike. The collective emotions are most evident in public spaces where they meet for group protests and council meetings to vote as a community and decide on a course of action to achieve their collective goal. James Jasper believes that emotions as situational, pervading all social life and therefore have a fundamental role in social movements and that "Not only are emotions part of our responses to events, but they also shape the goals of our actions" ("Constructing Indignation: Anger Dynamics in Protest Movements," 2014, 213). The movie underscores anger as both a response to a specific event, which was prompted by the neo-liberal globalized market and also as what catalyzes and motivates action to achieve a collective goal.

To conclude, Even the Rain depicts characters that display emotions governed by their sociocultural standards that are heavily influenced by political and economic situation of the time, globalization, and neo-liberal capitalism for the westerners and elite government officials and the Andean cosmology based on living in harmony with the Earth for the natives. Also we see that emotions are indeed rational to a certain point and that in fact, they work in accordance with rationality to achieve individual and collective goals. What interests me the most in the film is that it reflects the way in which emotions are truly how humans engage with the world. Through experiencing authentic emotions as Costa did with Daniel's family, we could change our way of perceiving and experiencing reality. What I am getting at is that perhaps the cultivation of certain emotions such as empathy for example is the key to the creation of Mignolo's utopic concept of a pluriversal society rather than discourse that will contradict the rationality of the market.

\section{Notes}

1. Two of the major figures of the new cinema movements of the 1960s and 1970s include Fernando Solanas and Octavio Getino, whose filmmaking group known as the Cine de liberación proposed the Third Cinema, which aimed to decolonize the culture in Argentina. Cine de liberación sought to destroy the imperialist image of reality by capturing true reality through guerrilla filmmaking (Martin 1997, 47).

2. The Price of Fire: Resource Wars and Social Movements in Bolivia (2007) by Benjamin Dangl for a detailed account of the Water Wars of Cochabamba.

\section{Works Cited}

Barbalet, J. M. Emotion, Social Theory, and Social Structure: A Macrosociological Approach. Cambridge: Cambridge University Press, 1998.

Bollaín, Icíar. También la lluvia. Madrid: Morena Films, 2010.

Dangl, Benjamin. Price of Fire: Resource Wars and Social Movements in Bolivia. Oakland: AK Press, 2007.

De, Sousa R. The Rationality of Emotion. Cambridge: MIT Press, 1987.

Jasper, James M. “Constructing Indignation: Anger Dynamics in Protest Movements.” Emotion Review 6.3 (2014): 208-13.

Martin, Michael T. New Latin American Cinema. Detroit: Wayne State University Press, 1997.

Meštrović, Stjepan Gabriel. Postemotional Society. London: SAGE, 1997. 
Mignolo, Walter, and MyiLibrary. The Darker Side of Western Modernity: Global Futures, Decolonial Options. Durham: Duke University Press, 2011.

Stearns, Peter N. American Cool: Constructing a Twentieth-Century Emotional Style. New York: New York University Press, 1994. 